\title{
Salt-taste responsivity in Long-Evans rats and Egyptian spiny mice treated with hydrochlorothiazide
}

\author{
SHERYL LOEFFLER and GARY M. BROSVIC \\ Rider College, Lawrenceville, New Jersey
}

\begin{abstract}
Sodium chloride $(\mathrm{NaCl})$ consumption $\left(3 \times 10^{-1} \mathrm{M}\right)$ by and $\mathrm{NaCl}$ and potassium chloride $(\mathrm{KCl})$ preferences of Long-Evans rats and Egyptian spiny mice were assessed prior to, during, and after maintenance on hydrochlorothiazide (HCTZ) or control procedures. The rats demonstrated increased sodium salt consumption and lowered $\mathrm{NaCl}$ preference thresholds and similar, although less robust, changes were observed for the spiny mice. No changes in salt-taste sensitivity were observed for the control animals.
\end{abstract}

In a recent report, we described substantial differences in the water and sodium chloride $(\mathrm{NaCl})$ consumption of Long-Evans rats and Egyptian spiny mice during acute water deprivation and furosemide challenge, with exaggerated consumption observed for rats and nominal changes observed for spiny mice (Kolodiy, Brosvic, Bailey, et al., 1993). In part, these differences were attributable to the spiny mouse's regulatory abilities, as would be expected of animals inhabiting arid environs (Brunjes, 1990); it would be of interest to determine whether similar outcomes would be observed during more extended periods of sodium deficiency.

The administration of selected natriuretics has been shown to alter salt-taste responsivity in humans (Langford, Watson, \& Thomas, 1976; Schiffman, Lockhead, \& Maes, 1983) and rats (Bernstein \& Hennesey, 1987; Contreras, Farnum, \& Bird, 1985; Olesen \& Thomsen, 1981), especially when amiloride or hydrochlorothiazide (HCTZ) are used. Amiloride has been reported to reduce salt-taste responsivity, whereas HCTZ has been reported to enhance salt-taste responsivity, and both agents readily induce bodily sodium deficiency. However, in a recent clinical study with humans, amiloride was reported to decrease salivary sodium levels and to lower $\mathrm{NaCl}$ recognition thresholds, whereas similar changes were not observed after treatment with HCTZ (Mattes, Christensen, \& Engelman, 1988).

These latter results were surprising, because the lowering of a recognition threshold is indicative of an enhancement rather than a decrement in responsivity. The absence of an $\mathrm{HCTZ}$ effect on $\mathrm{NaCl}$ recognition thresholds was surprising, especially because the administration of HCTZ to rats for several days markedly lowered $\mathrm{NaCl}$ preference thresholds (Fregly, 1967). Thus, the present study was undertaken to examine the effects of chronic HCTZ

This project was supported in part by the Summer Fellowship Program of Rider College. Address correspondence to G. M. Brosvic, Department of Psychology, Biopsychology Laboratory, Rider College, 2083 Lawrenceville Road, Lawrenceville, NJ 08648-3099. administration on the salt-taste responsivity of Long-Evans rats and Egyptian spiny mice.

\section{METHOD}

Subjects

Nine adult male and 9 adult female inbred Long-Evans hooded rats (Rattus norvegicus) and 12 male and 11 female inbred Egyptian spiny mice (Acomys cahirinus) served as subjects. The animals were housed in polystyrene cages in a temperature- and humidity-controlled vivarium with houselights on between 0600 and $1800 \mathrm{~h}$.

\section{Taste Preference Test Procedure}

Taste preferences for reagent-grade aqueous solutions of $\mathrm{NaCl}$ and $\mathrm{KCl}$ were examined at concentrations ranging from $1 \times 10^{-3}$ to $5 \times 10^{-1} \mathrm{M}$. Preference behavior was examined in separate 2-h test sessions in which the animals were presented with two bottles-one containing a tastant dissolved in water and the other containing only water. Bottle positions were randomized to control for potential position effects and test results were expressed in terms of percent preference according to the following formula: amount of tastant solution (in milliliters) $\times 100 /$ total intake of tastant solution and water (in milliliters).

\section{General Procedure}

Preference thresholds for $\mathrm{NaCl}$ and $\mathrm{KCl}$ and the consumption of $2.5 \times 10^{-1} \mathrm{M} \mathrm{NaCl}$ were assessed for all the animals during baseline, HCTZ treatment, and recovery. Upon the completion of baseline testing, two groups of rats and two groups of mice were matched for both $\mathrm{NaCl}$ and $\mathrm{KCl}$ preference and $\mathrm{NaCl}$ consumption and then randomly designated to serve as either control or experimental groups. During the HCTZ-treatment phase, the experimental animals were maintained on ad-lib access to $0.1 \%$ HCTZ (Sigma Corp.) dissolved in drinking water, for a total of 7 weeks. HCTZ was then removed from the experimental animals' drinking bottles to initiate the 3-week recovery phase. The control animals were treated in an identical manner during each phase of the study, with the exception that their drinking bottles did not contain HCTZ.

It should be noted that spiny mice typically reject $\mathrm{NaCl}$, so the two groups of mice were matched on percent preference for the value of the rat's $\mathrm{NaCl}$ preference threshold $\left(3 \times 10^{-2} \mathrm{M}\right)$.

\section{RESULTS}

\section{HCTZ Consumption}

In two-bottle preference tests, both the rats and the spiny mice demonstrated approximately equivalent preferences for both water and $0.1 \% \mathrm{HCTZ}$ dissolved in water. Thus, 


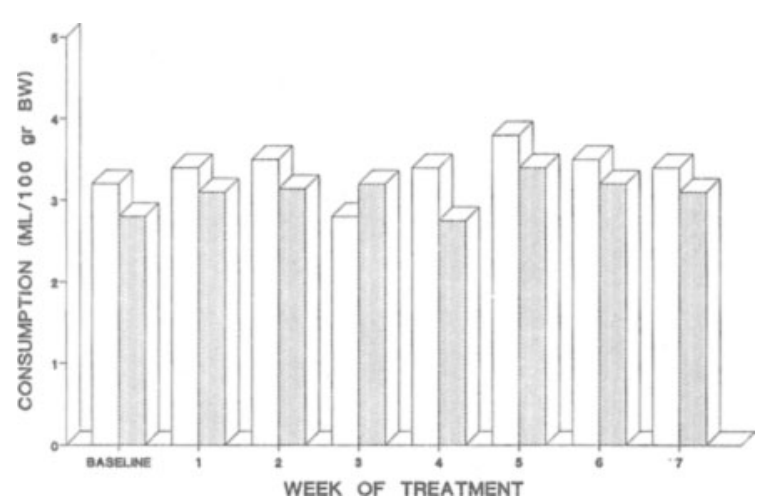

Figure 1. HCTZ consumption (milliliters per $100 \mathrm{~g}$ body weight) by rats (open bars) and spiny mice (hatched bars) during baseline and the 7-week HCTZ-treatment period.

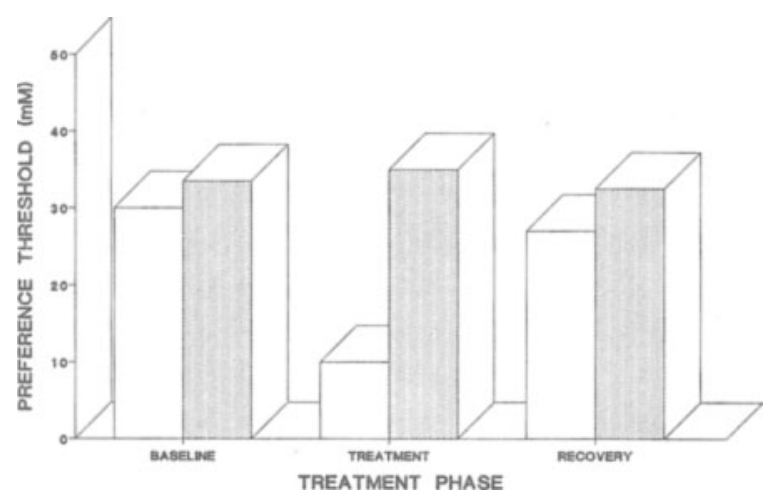

Figure 2. Median $\mathrm{NaCl}$ preference thresholds (millimoles) of HCTZ-treated rats (open bars) and control rats (hatched bars).

the experimental outcomes described below do not appear to have been influenced by the potential for conditioned taste aversions. The daily consumption of HCTZ for each murid strain is shown in Figure 1 as a function of the number of milliliters consumed per $100 \mathrm{~g}$ of body weight. No significant differences in adjusted HCTZ consumption were observed between the rats and the spiny mice at any point during the study (all $t \mathrm{~s}<1$, all $p \mathrm{~s}>.05$ ).

\section{Preference Thresholds}

The rats' median preference threshold for $\mathrm{NaCl}$, as seen in Figure 2, was approximately $3 \times 10^{-2} \mathrm{M}$ prior at baseline, decreased significantly to approximately $1 \times 10^{-2} \mathrm{M}$ during HCTZ treatment, and then returned to normal limens during the recovery period $(F=16.27, p<.05)$. No significant changes in $\mathrm{NaCl}$ preference thresholds for control rats (approximately $3 \times 10^{-2} \mathrm{M}$ ) were observed at any point during the study.

In contrast, the spiny mice rejected each $\mathrm{NaCl}$ solution; for presentation purposes, preferences for $3 \times 10^{-2} \mathrm{M} \mathrm{NaCl}$ are presented in Figure 3. The median preference shown by the spiny mice for the $\mathrm{NaCl}$ solution was $28 \%$ at baseline-a value that increased to a median of $55 \%$ by Week 3 of HCTZ treatment, and then reversed toward normal limens during the recovery period $(F=4.15, p<$ $.05)$. The spiny mice tested as controls rejected $3 \times 10^{-2} \mathrm{M}$ $\mathrm{NaCl}$, and no change in $\mathrm{NaCl}$ preference behavior was observed during the course of the study.

Preference thresholds for $\mathrm{KCl}$ did not differ between the HCTZ-treated rats and the control rats at any point during the study. The spiny mice rejected $\mathrm{KCl}$ at each concentration presented, which was an outcome similar to that described by Kolodiy, Brosvic, Pak, and Loeffler (1993).

\section{Salt Intake}

The rats' daily consumption of $2.5 \times 10^{-1} \mathrm{M} \mathrm{NaCl}$ is shown in Figure 4 as a function of percent change from baseline. Relative to baseline, significant increases were observed by Week 2 of HCTZ treatment. The rats' exaggerated $\mathrm{NaCl}$ consumption continued through the remaining 5 weeks of HCTZ treatment and then reversed toward baseline levels during the recovery period $(F=7.81, p<$ $.05)$.

The daily consumption of $2.5 \times 10^{-1} \mathrm{M} \mathrm{NaCl}$ by the spiny mice is shown in Figure 5 as a function of percent change from baseline. Relative to baseline, significant increases were observed by Week 4 of HCTZ treatment, and the exaggerated consumption of $\mathrm{NaCl}$ reversed toward baseline levels during the recovery period $(F=3.07, p<$ $.05)$.

During each HCTZ-treatment week, the rats' consumption of $2.5 \times 10^{-1} \mathrm{M} \mathrm{NaCl}$ was significantly greater than that observed for the spiny mice (all $t \mathrm{~s}>6.29$, all $p \mathrm{~s}<$ $.05)$. No changes in salt consumption for the control rats or the control spiny mice were observed at any point during the study (all $F \mathrm{~s}<1$, all $p \mathrm{~s}>.05$ ).

\section{DISCUSSION}

Although water and $\mathrm{NaCl}$ consumption and taste preference behavior have been reported to differ substantially between Long-Evans rats and Egyptian spiny mice (Kolodiy, Brosvic, Bailey, et al., 1993; Kolodiy, Brosvic, Pak, \& Loeffler, 1993), relatively similar effects of HCTZ on sodium salt intake were observed for these two murid strains in the

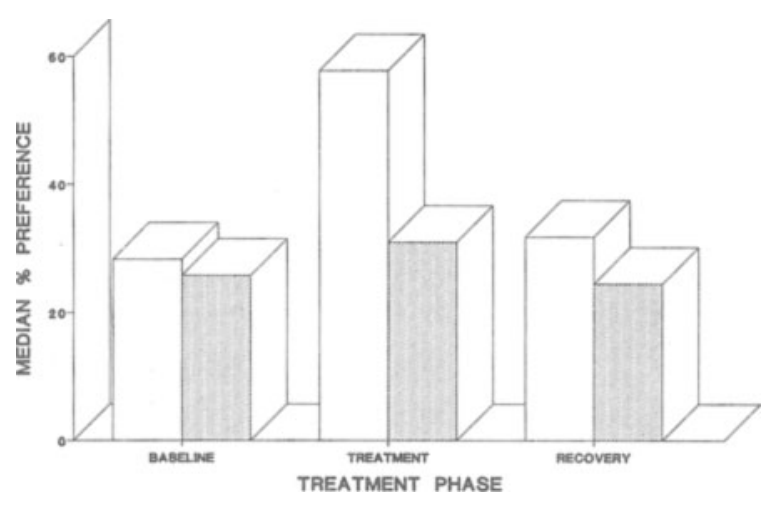

Figure 3. Median percent preference for $3 \times 10^{-2} \mathrm{M} \mathrm{NaCl}$ by HCTZ-treated spiny mice (open bars) and control mice (hatched bars). 


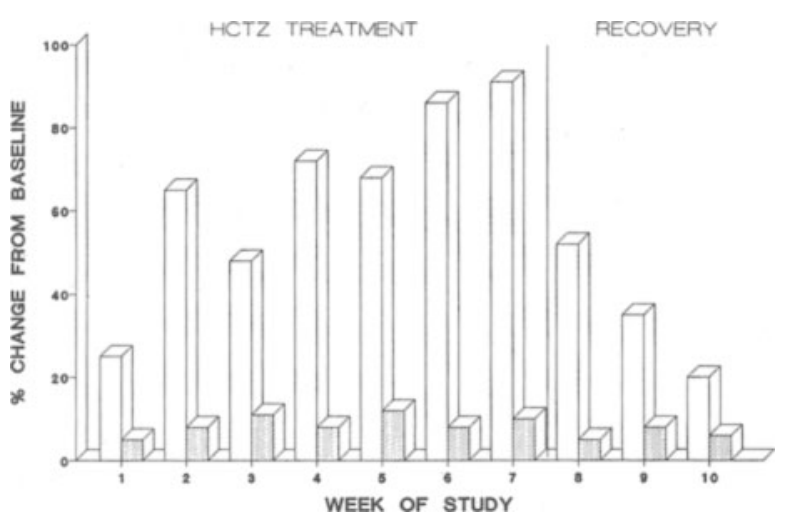

Figure 4. Consumption of $2.5 \times 10^{-2} \mathrm{M} \mathrm{NaCl}$ by HCTZ-treated rats (open bars) and control rats (hatched bars) during HCTZ treatment (Weeks 1-7) and recovery (Weeks 8-10). Data values are plotted as the median percent change from baseline.

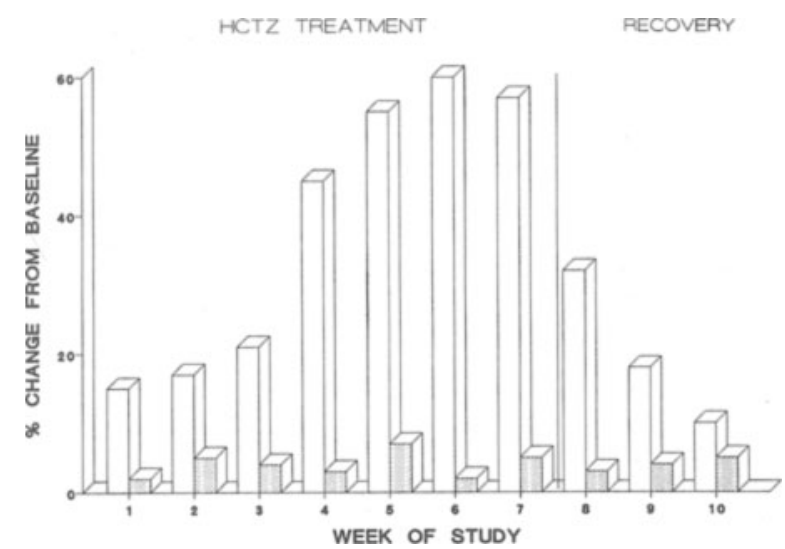

Figure 5. Consumption of $2.5 \times 10^{-2} \mathrm{M} \mathrm{NaCl}$ by HCTZ-treated spiny mice (open bars) and control mice (hatched bars) during HCTZ treatment (Weeks 1-7) and recovery (Weeks 8-10). Data values are plotted as the median percent change from baseline.

present study. The rats' preference threshold for $\mathrm{NaCl}$ decreased from $3 \times 10^{-2}$ to $1 \times 10^{-2} \mathrm{M}$, suggesting an increase in $\mathrm{NaCl}$ sensitivity. The rejection of $\mathrm{NaCl}$ by the spiny mice precluded the determination of a baseline $\mathrm{NaCl}$ preference threshold; however, the increased preference for $3 \times 10^{-2} \mathrm{M} \mathrm{NaCl}$ observed during HCTZ treatment suggests some congruence between the two strains' $\mathrm{NaCl}$ preference thresholds, at least during periods of chronic sodium deficiency. Generally, the changes in salt-taste responsivity observed in the present study are similar to those reported in a variety of clinical studies with humans (e.g., Bertino, Beauchamp, \& Engelman, 1982, 1986; Langford et al., 1976), and the absence of changes in preferences for $\mathrm{KCl}$ most likely indicates that HCTZ's effects were specific to the loss of bodily sodium.
The altered salt-taste responsivity in Long-Evans rats appears to be similar to that described by Fregly (1967) when HCTZ was mixed with laboratory chow and Carworth CFN rats were tested. The preference threshold values observed by Fregly and in the present study may be related to changes in the $\mathrm{Na}^{+} / \mathrm{K}^{+}$ratio in saliva, although no changes in that ratio or for salt-taste sensitivity were observed for humans treated with therapeutic doses of HCTZ (Mattes et al., 1988). It is possible that Mattes et al.'s results are characteristic of normotensive subjects, especially because most prior clinical studies in which diuretics have been reported to alter salt-taste sensitivity have also evaluated subjects with varying degrees of hypertension (Langford et al., 1976). However, direct comparison of threshold values is precluded by substantial differences in measurement paradigms and control procedures. Studies examining the potential effects of varying degrees of the rat's genetic predisposition to hypertension on salt appetite are currently in progress.

\section{REFERENCES}

Bernstein, I. L., \& HenNesey, C. J. (1987). Amiloride-sensitive sodium channels and expression of sodium appetite in rats. American Journal of Physiology, 253, R371-R374.

Bertino, M., Beauchamp, G., \& Engelman, K. (1982). Long-term reduction in dietary sodium alters the taste of salt. American Journal of Clinical Nutrition, 36, 1134-1144.

Bertino, M., Beauchamp, G., \& Engelman, K. (1986). Increasing dietary salt alters salt taste preference. Physiology \& Behavior, 38, 203-213.

Brunjes, P. C. (1990). The precocial mouse, Acomys cahirinus. Psychobiology, 18, 339-350.

Contreras, R. J., Farnum, E. K., \& Bird, E. (1985, April). Amiloride alters behavioral and neural gustatory responses to salt solutions. Paper presented at the meeting of the Chemoreception Sciences, Sarasota, FL.

FreGLY, M. J. (1967). Effect of hydrochlorothiazide on preference threshold of rats for $\mathrm{NaCl}$ solutions. Proceedings of the Society for Experimental Biology \& Medicine, 125, 1079-1084.

Kolodiy, N., Brosvic, G. M., Bailey, S., Hawley, K., PaK, D., \& Ostrich, S. (1993). Water and $\mathrm{NaCl}$ consumption in Long-Evans rats and Egyptian spiny mice. Bulletin of the Psychonomic Society, 31, 261-264.

Kolodiy, N., Brosvic, G. M., PAK, D., \& LoefFler, S. (1993). Taste preference behavior in Long-Evans rats and Egyptian spiny mice. Bulletin of the Psychonomic Society, 31, 307-310.

LANGFord, H. G., Watson, R. L., \& Thomas, J. G. (1976). Salt intake, diuretics, and the treatment of hypertension. American Clinical Climatology, 88, 32-37.

Mattes, R. D., Christensen, C. M., \& Engelman, K. (1988). Effects of therapeutic doses of amiloride and hydrochlorothiazide on taste, saliva, and salt intake in normotensive rats. Chemical Senses, 13, 33-44.

Olesen, O. V., \& Thomsen, K. (1981). A comparison between the natriuretic response to potassium in lithium- and amiloride-treated rats. Acta Pharmacologia \& Toxicology, 48, 382-389.

Schiffman, S. S., Lockhead, E., \& MaEs, F. W. (1983). Amiloride reduces the taste intensity of $\mathrm{Na}^{+}$and $\mathrm{Li}^{+}$salts and sweeteners. Proceedings of the National Academy of Sciences, 80, 6136-6140.

(Manuscript received June 25, 1993.) 